\title{
Company bankruptcy and its prediction in conditions of globalization
}

\author{
Peter Adamko, Jan Chutka ${ }^{2, *}$ \\ ${ }^{1}$ University of Zilina, Faculty of Operation and Economics of Transport and Communications, \\ Department of Quantitative Methods and Economic Informatics, Univerzitna 1, 01026 Zilina, Slovak \\ Republic \\ ${ }^{2}$ University of Zilina, Faculty of Operation and Economics of Transport and Communications, \\ Department of Economics, Univerzitna 1, 01026 Zilina, Slovak Republic
}

\begin{abstract}
The internationalisation and globalisation of today's world, especially in business, brings whole new range of opportunities, challenges and also many kinds of risks. Today's global market in process of globalization offers many different ways of doing business and also whole new ranges of methods how to analyse optimize and also minimize it's risks. The issue of bankruptcy models is still relevant given by the high competition in the markets and the increasingly frequent crises. Not only in the world, but also in our country, we can see a huge number of bankruptcies of businesses. If the company wants to thrive and successfully compete in the market environment, it should conduct a regular financial analysis of its activities, evaluate successes and failures, and use the results obtained to make strategic decisions about future business development. The aim of the article is to examine the possibilities of predicting the bankruptcy of companies and describe their individual procedures. In the first part of the paper we defined the terms such as insolvency, decline of company and bankruptcy. We continue with a brief overview of the development of bankruptcy models from the first attempts to modern practices. We have described and defined each model in detail, described its specifics, and described the calculation procedure. The biggest added value of this paper is a comprehensive elaboration of an overview of the possibilities of predicting company manrots through bankruptcy models. We can say that the goal of the post has been fulfilled.
\end{abstract}

\section{Introduction}

Businesses are currently in an economic environment that is constantly evolving and changing, depending on many different factors. After the centrally planned economy and the transition to a market economy system, firms in the Slovak Republic had to adapt not only to the changing state system, but also to the harsh emerging competitive environment. After more than a decade of transition, businesses faced another challenge, namely joining the European Union and then Schengen. This opening of economic space has given businesses a huge market, covering almost the whole of Europe, with many business

\footnotetext{
* Corresponding author: jan.chutka@fpedas.uniza.sk
} 
opportunities but also new competitors. Survival in such an economic environment requires not only maintaining its business competitive advantage, but also quality financial management of the company, for which knowledge of the company's financial condition is important.

\section{Methodology}

The issue of forecasting the future development of the company's financial condition has been addressed by many economics since the beginning of the second half of the last century. The main aim of their scientific work was primarily to create models that would be able to predict with a sufficient degree of probability the future development of the company in advance. Multidimensional models assessing the overall financial situation of a company have proven to be one of the best methods by providing a single result value by combining individual ratios. This resulting value should be able to predict how the financial condition of the company will develop. The two main groups of multidimensional models are creditworthy and bankruptcy models. However, the distinction between creditworthy and bankruptcy models is not always so firm, as there are some creditworthy models capable of predicting the company's future insolvency, which in most cases is a precursor to bankruptcy. If we want to try to predict the bankruptcy of a company, it is necessary to define the basic terms.

\subsection{Crisis in enterprises}

In crisis management of the company, the problem is the precise definition of the concept of corporate crisis. In M. Synka, E. Kislinger et al. refers to: a stage in the life of an enterprise where, over a prolonged period of time, its performance potential unfavorably develops, a radical decrease in sales volume, a decrease in net assets, a reduction in liquidity, which directly threatens its continued existence if this development will continue [14]. Zuzak and König understand the crisis as a situation of varying length of time, in which the company decides whether to return to the pre-crisis state, or if the achievement of its business goals or the company's survival is prospectively threatened [19]. H. Pollak agrees with the previous authors and identifies the crisis as an economic situation in which the existence of a company is in jeopardy and its redevelopment is necessary [10].

\subsection{Causes of the crisis}

The reasons for which firms get into crises are the innumerable number, and they can operate individually or more at once. There are several divisions of causes of corporate crises in the scientific literature. This issue is dealt with by a very comprehensive publication by Zuzak and Königova, from which the theoretical basis for this subchapter is drawn. The causes of the business crisis can be caused by the different risk situations in which the business may be located [19].

In his publication Zuzak divides them as follows [19]:

1) Internal and external economic risks - In this case, risk factors from other areas are projected. The company has a limited opportunity to influence them, but is able to predict the effects of some factors and to some extent to insure against them.

2) Supply and customer risks - These risks may be caused directly by the supplier and the customer or arise from force majeure. A common phenomenon is passing the problems of the supplier or customer to the company.

3) Manufacturing, technical and technological risks - These are risks resulting from the operation of technological equipment, for example, fatigue of material, failure 
to maintain or operator error. Subsequent product offerings may lack certain technical parameters or required quality.

4) Information risks - Information risks are divided into three groups, data, software and hardware. This is primarily the failure of information systems, data security and software from misuse.

5) Social or occupational risks - In this case, the behavior of workers is in most cases a reflection of the employer-employee relationship and also the perception of the business by customers.

6) Market risks - They arise from the business activities of the enterprise towards the surroundings. Customers and competitors can respond to these activities, endangering business goals with potentially undesirable financial impact.

7) Political risks - There may be a variety of business-undesirable situations when changing or behaving political systems.

8) Legislative risks - Consequences for undertaking adverse changes in legislation, whether in its own state or in the state of commerce. Business interest should be an effort, individually or through 'lobbying' groups, to change or mitigate such legislation.

\subsection{Symptoms of crisis}

In the previous sub-chapter, the reasons why businesses could go into crisis were presented. But how to identify this unfavorable situation in advance? The views vary across experts, but what is extremely important for companies is to be able to detect the coming crisis in a timely manner. According to Pollak, the first signs that a company is in trouble have been reflected in the management of the company for several years before they reach the financial statements. It adds that this is mainly due to management's efforts to conceal the adverse situation of the company. It defines the main symptoms as follows [10]:

1) Lack of management - The primary cause of problems in the company is unqualified or narrowly focused management. For small or family businesses, it is often the case that one dominant person is in the management of a company, who is difficult to replace after leaving and the company is subsequently sentenced to dissolution.

2) Slow response to change - It is known from practice that a fast-growing, successful enterprise will become cumbersome due to slow reactions to new circumstances and self-satisfaction. Management is focused on the success of the past and overlooks the gradually emerging shortcomings, which leads to decreasing product quality or obsolescence, shortage in the organization of the company, backward production technology and others.

3) Insufficient information system - The third symptom of emerging problems in the company is the failure of communication. However, the primary concern is not the insufficient number of reports or statistics within the company, but their sufficient selection. Unless accurate and targeted information is available to management, it is not possible for it to make informed and beneficial business decisions.

\subsection{Altman's bankruptcy model}

The Altman model (1968) is without a doubt one of the best known bankruptcy models. E. I. Altman analyzed 66 businesses, one half being prosperous and the other half bankrupt. He chose companies between 1946 and 1965. The author identified 22 potential financial indicators, which can be divided into 5 groups: indicators of activity, liquidity, profitability, indebtedness and solvency. Finally, he developed a discriminatory function consisting of five financial indicators, which he used to calculate the $\mathrm{Z}$ score $[2,4]$. 


$$
Z=1,2 X_{1}+1,4 X_{2}+3,3 X_{3}+0,6 X_{4}+1 X_{5}
$$

$\mathrm{X} 1=$ net working capital / assets

$\mathrm{X} 2$ = retained profit / capital

$\mathrm{X} 3=$ profit before interest and taxes / capital

$\mathrm{X} 4$ = market value of equity / foreign capital

$\mathrm{X} 5=$ sales / capital

The interpretation of $\mathrm{Z}$ score is as follows:
$Z>2.90$
$1.81<\mathrm{Z} \leq 2.90$
the financial situation is good
$\mathrm{Z} \leq 1.81$
the so-called gray zone
critical financial situation, threatening bankruptcy

As a result of the specifics, Altman constructed a model for US publicly traded companies in 1983. In Indicator X4, in market capitalization he used equity. The new discriminatory function already had other weights for variables and limits for determining bankruptcy [3].

$$
Z=0,717 X_{1}+0,847 X_{2}+3,107 X_{3}+0,420 X_{4}+0,998 X_{5}
$$

The interpretation of $\mathrm{Z}$ score is as follows:
$Z>2.60$
$1.10<Z \leq 2.60$
the financial situation is good
$\mathrm{Z} \leq 1.10$
the so-called gray zone
critical financial situation, threatening bankruptcy

\subsection{Tafler model}

Another model that assesses the risk of bankruptcy is the Taffler model (1983), which is based on the Altman model methodology. Taffler considered that the indicators of the degree of funding and profitability were decisive for predicting bankruptcy. Liquidity indicators are less important. The design was based on a sample of British manufacturing companies from 1969 to 1975 , half of them bankrupt and the other half showed no signs of a bad financial situation. The Taffler model (1983) uses four ratios: profitability, financial risk, working capital adequacy and liquidity.

$$
\mathrm{T}=0,53 \mathrm{X}_{1}+0,13 \mathrm{X}_{2}+0,18 \mathrm{X}_{3}+0,16 \mathrm{X}_{4}
$$

$\mathrm{X} 1=$ profit before interest and taxes / short - term liabilities

$\mathrm{X} 2$ = current assets $/$ foreign capital

$\mathrm{X} 3=$ short - term liabilities $/$ total assets

$\mathrm{X} 4=$ sales $/$ total assets

If the value of $\mathrm{T}>0.3$ this means a very low probability of bankruptcy, the company is highly liquid. If $\mathrm{T}<0.2$ the company is in a risk area, which predicts a high probability of bankruptcy. The authors recommend comparing only companies within the same sector.

\subsection{Indexes IN}

The IN index group includes 4 models based on mathematical statistics methods. The acronym IN bears the initials of the creators, spouses Inca and Ivan Neumeier. These are bankruptcy models used to predict the financial health of businesses in the Czech Republic, more precisely industrial enterprises. The Czech Republic and the Slovak Republic are similar in several economic fundamentals, therefore it is possible to successfully apply 
these methods also in our conditions in the Slovak Republic. The first model was IN95, which was later modified to IN99, IN01 and finally to the latest version of IN05.

\subsubsection{IN 95}

The IN95 index is also referred to as the trust index or creditor model. The construction of the index is based on the financial statements of Czech companies and is the result of an analysis of 24 empirical-inductive indicator systems [2, 5]. IN95 does not contain any indicator working with the market value of the company. The index was verified on the data of thousands of Czech companies in 1994 and the index shows a 70\% success rate prediction of the company's financial situation.

$$
\text { IN95 }=V_{1} X_{1}+0,11 X_{2}+V_{3} X_{3}+V_{4} X_{4}+0,10 X_{5}+V_{6} X_{6}
$$

$\mathrm{X} 1=$ total assets / foreign capital

$\mathrm{X} 2=\mathrm{EBIT} /$ interest expense

$\mathrm{X} 3=\mathrm{EBIT} /$ total assets

$\mathrm{X} 4=$ total revenues $/$ total assets

$\mathrm{X} 5=$ current assets $/$ short-term external resources

$\mathrm{X} 6=$ overdue payables / sales

The interpretation of IN95 is as follows:

IN95 $>2.00$ the enterprise outside financial distress

$1.01<$ IN95 $\leq 1.99$ the so-called gray zone

IN95 $\leq 1.10$ the enterprise is in financial distress

\subsubsection{IN 99}

The IN99 index focuses on the performance component of the business, which is the meaning of the existence of the business and represents the main interest of the owner. The success rate of this index is higher than $84 \%$. IN99 adjusts the weights used in the IN95 index to achieve a positive EVA value.

$$
\text { IN99 }=-0,017 X_{1}+4,573 X_{2}+0,481 X_{3}+0,015 X_{4}
$$

$\mathrm{X} 1=$ total assets $/$ foreign capital

$\mathrm{X} 2=\mathrm{EBIT} /$ total assets

$\mathrm{X} 3=$ total revenues $/$ total assets

$\mathrm{X} 4=$ current assets / short-term external resources

The interpretation of IN95 is as follows:

IN99 $>2.07$ the company achieves positive economic profit

$1.42 \leq$ IN99 $\leq 1.99$ an ambiguous situation, but the enterprise is more of a value

$1.089 \leq \mathrm{IN} 99 \leq 1.42$ it is a problem to determine whether or not an enterprise creates value

$0.684 \leq \mathrm{IN} 99 \leq 1.089$ rather, the enterprise does not create value

IN95 $<0.684$ the company has a negative economic profit 


\subsubsection{IN 01}

The index IN01 is referred to as a complex variant of the IN index. This index is the result of a discriminatory analysis of the financial indicators of 1915 enterprises, which were divided into a group of 583 value-generating enterprises, a group of 503 bankruptcy enterprises and 829 other enterprises. It is mainly used in industry and has a bankruptcy character $[6,12]$. The index shows a success rate of $74 \%$ for bankruptcy and $69 \%$ success for value creation. The form of the discriminatory function is as follows:

$$
\text { IN01 }=0,13 \mathrm{X}_{1}+0,04 \mathrm{X}_{2}+3,92 \mathrm{X}_{3}+0,21 \mathrm{X}_{4}+0,09 \mathrm{X}_{5}
$$

$\mathrm{X} 1=$ total assets $/$ foreign capital

$\mathrm{X} 2=\mathrm{EBIT} /$ interest expense

$\mathrm{X} 3=\mathrm{EBIT} /$ total assets

$\mathrm{X} 4=$ total assets / foreign capital

$\mathrm{X} 5$ = current assets / short-term external resources

\subsection{Springate model}

The Springate model was created in 1978 by Gordon L.V. Springate based on Altman model. Based on a multidimensional discriminatory analysis, he chose 4 out of 19 ratios. This model chooses indicators to identify shortcomings in the areas of revenue, liquidity and profit $[8,11]$.

$$
S=1,03 A+3,07 B+0,66 C+0,4 D
$$

$\mathrm{A}=$ net working capital / assets

$\mathrm{B}=\mathrm{EDIT} /$ assets

$\mathrm{C}=\mathrm{EBT} /$ short-term liabilities

$\mathrm{D}=$ sales / assets

The model achieves a $92 \%$ success rate prediction of financial problems when applied to 40 businesses. If the values of $\mathrm{S}$ are less than 0.862 , then we can very likely expect some problems because the company has poor financial health.

\subsection{Fulmer model}

This model was published by Professor Fulmer in 1984. The Fulmer model is designed for small and medium-sized businesses. It originally analyzed 60 companies using 40 indicators. Half of the businesses were successful and the other half showed financial problems. The author reports a $98 \%$ accuracy rate for one year before bankruptcy and an $81 \%$ accuracy rate for more than one year before bankruptcy. If the value of $\mathrm{F}>0$ the company is without problems, but if the value of $\mathrm{F}<0$, the company is going into bankruptcy $[9,15]$. The form of the discriminatory function is as follows:

$$
\begin{array}{ll}
\mathrm{F}=5,528 \mathrm{X}_{1}+0,212 \mathrm{X}_{2}+0,07 \mathrm{X}_{3}+1,27 \mathrm{X}_{4}-0,12 \mathrm{X}_{5}+2,335 \mathrm{X}_{6}+0,575 \mathrm{X}_{7}+1,083 \mathrm{X}_{8}+0,894 \mathrm{X}_{9}-6,075 \\
\mathrm{X} 1=\text { retained earnings / assets } & \mathrm{X} 6=\text { current liabilities / assets } \\
\mathrm{X} 2=\text { sales / assets } & \mathrm{X} 7=\text { logarithm tangible fixed assets } \\
\mathrm{X} 3=\text { EBT / equity } & \mathrm{X} 8=\text { net working capital / foreign capital } \\
\mathrm{X} 4=\text { cash flow / foreign capital } & \mathrm{X} 9=\log (\mathrm{EBIT} / \text { interest expense }) \\
\mathrm{X} 5=\text { debts / assets } &
\end{array}
$$




\subsection{Beerman model}

The Beerman model was created using discriminatory analysis and is used to assess and forecast the financial-economic situation, particularly in manufacturing companies. The author does not recommend using this method in commercial companies. According to Beerman, the following 10 indicators are relevant [14]:

$\mathrm{X} 1$ = depreciation of tangible fixed assets / Initial balance of tangible fixed assets + Increment

$\mathrm{X} 2$ = additions to tangible fixed assets / depreciation of tangible fixed assets

$\mathrm{X} 3=\mathrm{EBT} /$ sales

$\mathrm{X} 4$ = liabilities to banks / foreign capital

$\mathrm{X} 5=$ inventory / sales

$\mathrm{X} 6=$ cash flow / foreign capital

$\mathrm{X} 7=$ foreign capital / assets

$\mathrm{X} 8=\mathrm{EBT} /$ assets

$\mathrm{X} 9=$ sales $/$ assets

$\mathrm{X} 10=\mathrm{EBT} /$ foreign capital

Based on discriminatory analysis, Beerman created the following formula:

$$
\begin{gathered}
\mathrm{BE}=0,217 \mathrm{X}_{1}-0,063 \mathrm{X}_{2}+0,012 \mathrm{X}_{3}+0,077 \mathrm{X}_{4}-0,105 \mathrm{X}_{5}-0,813 \mathrm{X}_{6}+ \\
0,165 \mathrm{X}_{7}+0,161 \mathrm{X}_{8}+0,268 \mathrm{X}_{9}+0,124 \mathrm{X}_{10}
\end{gathered}
$$

\section{Results}

The previous chapters offered us an insight into the issue of the company's bankruptcy prediction. We had the opportunity to find out that there are many ways to predict the default situation. But how to find out which model is the most suitable? The answer to this question is simple. The best model is one that minimizes type 1 and type 2 errors while showing a high percentage of correct classification [7, 17]. However, the problem may arise at the moment when it is necessary to determine a particular model or at least the method that would be most accurate in a given situation. From this we can deduce why such a large number of bankruptcy models and their modifications are used. Many authors such as Anadarajan et al., or Shunway find the early causes of this problem [1,13]. The main point is that each author uses different time periods when creating his model, classifies bankrupt companies in different ways, different sample of companies, sample is created in the countries of the country, but the fact that the ratio of bankrupt entrepreneurs $\mathrm{v}$ differs in the examined samples. Even studies that deal with the problem of evaluating individual methods often times to conflicting results. Muller, Steyr-Bruwer and Hamman tried to compare some selected techniques [7, 16]. The aim of their work was to investigate whether some techniques predicted bankruptcy with better predictive power than others. The comparison was made on data of South African stock exchange companies. As a result of their analysis, each method produced different results. Next, they tried to test the effectiveness of the individual bankruptcy models $\mathrm{Wu}$, Gaunt and Gray [18]. They conducted 49,724 non-bankruptcy and 887 bankruptcy American companies that were traded on the stock exchange. Their outcome was that multiple discriminant analysis yielded worse results than other models used. The results of the logit and probit models were fair, especially during the first years of the reporting period, which was in the years 1980-2006, and over time their predictive skills deteriorated. 


\section{Discussion}

Based on these statements, we can say that the need to predict possible bankruptcy of companies is high. This may be due to the need to effectively minimize investment or credit risk, or to identify potential problems in a timely manner and to try to avert bankruptcy. There are many models of bankruptcy prediction in the world, and even more changes and modifications. This may be due to the high need for bankruptcy prediction or the absence of a generally valid model. From the mentioned individual descriptions of the models, their quantification, but mainly from the quantities involved in the calculation, we can see the effort to optimize individual calculations in order to identify potentially bankrupt company as effectively as possible. However, this optimization inevitably results in individual models functioning only under specific conditions. Individual models are targeted and optimized to deliver good performance only in a particular economic sector, in a particular market situation, only when applied to a business in a particular region and so on. If there is an effort to unify and develop a universal predictive bankruptcy model, then research should take exactly the opposite direction, namely the generalization of the individual variables examined. However, this can be hindered by different legislative amendments to tax reporting.

\section{Conclusion}

The aim of the article was to examine the possibilities of predicting the bankruptcy of companies and describe their individual procedures. In the first part of the paper we defined the terms such as insolvency, decline of company and bankruptcy. We continued with a brief overview of the development of bankruptcy models from the first attempts to modern practices. We have described and defined each model in detail, described its specifics, and described the calculation procedure. The biggest added value of this paper is a comprehensive elaboration of an overview of the possibilities of predicting company manrots through bankruptcy models. We can say that the goal of the post has been fulfilled.

The paper is an output of the science project VEGA 1/0428/17 Creation of new paradigms of financial management at the threshold of the 21st century in conditions of the Slovak republic.

\section{References}

1. Anadarajan, M., Lee, P., Anadarajan, A., Bankruptcy prediction of financially stressed firm: an examination of the predictive accuracy of artificial neural networks. Int. J. Intell. Syst. Acc. Fin. Mgmt 10, 69-81. (2001)

2. Cisko, S., Kliestik, T., Company Financial Management II. Zilina: Edis - Publishing ZU. ISBN 978-80-554-0684-8. (2013)

3. Fernandez-Gamezi, M. A., Dieguez-Soto, J., Santos, Jose Antonio C., et al., Bankruptcy prediction of family firms using combined classifiers. Journal of Scientific \& Industrial Research 78, 269-273. (2019)

4. Gavurova, B., Packova, M., Misankova, M., Smrcka, L., Predictive potential and risks of selected bankruptcy prediction models in the Slovak business environment. Journal of Business Economics and Management 18, 1156-1173. (2017)

5. Kliestik T., Kocisova K., Misankova, M., Logit and probit model used for prediction of financial health of company. Procedia - Economics and finance 23, 850-855. (2015)

6. Kovacova, M., Kliestik, T., Logit and probit application for the prediction of bankruptcy in Slovak companies. Equilibrium. Quarterly Journal of Economics and Economic Policy 12, 775-791. (2017) 
7. Muller, G. H., Steyn-Bruwer, B. W., Hamman, W.D., Predicting financial distress of companies listed on the JSE - a comparison of techniques. South African Journal of Business Management 40, 21-32. (2009)

8. Nyitrai, T., Virag, M., The effects of handling outliers on the performance of bankruptcy prediction models. Socio-economic Planning Sciences 67, 34-42. (2019)

9. Pernsteiner, H., Wagner, E., Kabat, L., et al., Doing business in new economic and social conditions. Bratislava: EUROKODEX. ISBN 978-80-89447-51-0. (2011)

10. Pollak, H., How to restore the viability of declining businesses. 1st edition. Prague: C.H. Beck, ISBN 80-7179-803-7. (2003)

11. Sadgrove, K., The Complete Guide to Business Risk Management. Burlington: Gower Publishing Company. ISBN 978-0566086618. (2005)

12. Sedlacek, J., Accounting data in manager's hands: financial analysis in company management. 2nd supplemented edition. Brno: Computer Press, ISBN 80-7226-562-8. (2001)

13. Shumway, T., Forecasting bankruptcy more accurately: A simple hazard model. Journal of Business 74, 101-124. (2001)

14. Synek, M., Kislingerova, E., Business economics 6th revised and supplemented edition. Prague: C.H. Beck, ISBN 978-807400-274-8. (2015)

15. Valaskova, K., Kliestik, T., Kovacova, M., Management of financial risks in Slovak enterprises using regression analys is. Oeconomia Copernicana 9,105-121. (2018)

16. Valaskova, K., Kramarova, K., Kollar, B., Theoretical aspects of a model of credit risk determination- Credit Risk. Advances in Education Research 81, 400-406. (2015)

17. Vochozka, M., Stehel, V., Rowland, Z., Krulicky, T. A review of the report on relation between the controlling and controlled party and between the controlled party and parties controlled by the same controlling party. Ad Alta- Journal of Interdisciplinary Research 9, 321-325. (2019)

18. Wu, Y., Gaunt, C., Gray, S., A comparison of alternative bankruptcy prediction models. Journal of Contemporary Accounting \& Economics. (2010)

19. Zuzak, R., Konigova, M., Enterprise Crisis Management 2nd updated and expanded edition. Prague: Grada, Expert. ISBN 978-80-247-3156-8. (2009) 